\title{
PENINGKATAN PROFESIONALISME GURU MELALUI WORKSHOP MEMBUAT INDIKATOR PENCAPAIAN KOMPETENSI KURIKULUM 2013 BAGI GURU PENDIDIKAN AGAMA HINDU TINGKAT SMA/K DI KABUPATEN BANGLI SEMESTER GANJIL TAHUN PELAJARAN 2018/2019
}

\author{
Oleh : \\ I Nyoman Wandri \\ Kantor Kementerian Agama Kabupaten Bangli \\ Wandri052@gmail.com
}

Diterima 11 Oktober 2018, direvisi 6 Pebruari 2019, diterbitkan 29 Maret 2019

\begin{abstract}
The aims of this study is to improve the teacher professionalism through workshops to make an indicator of the achievement of 2013 curriculum competencies for teachers of Hindu religious education at senior high school in Bangli Regency. This study was a School Action Research (PTS) which using three cycles design and each cycle consists of four stages, namely: planning, action, observation, and reflection. A measurement technique in the form of test is used to obtain a quantitative data, and an observation sheet is used to presented the qualitative data. The data was analyzed by using descriptive analysis. Furthermore, based on the results of this study, first at the end of the first cycle the increase of the average professionalism of teachers through workshops made the 2013 Curriculum Competency Achievement Indicator from the previous training was 64.22 to 73.4. Then, after the third cycle the professional level of teachers made the 2013 Curriculum Competency Achievement Indicator become 78.94 reaches the predicate of good value. Second, it turned out that the increase of the teacher professionalism through workshops made the Indicator of 2013 Curriculum Competency Achievement for Hinduism teachers at Senior High School in Bangli Regency in the academic year 2018/2019 shows very significant results from the initial conditions before receiving the training.
\end{abstract}

Keywords: Increasing Teacher Professionalism Through Workshop Making Indicators for Achieving 2013 Curriculum Competencies.

\section{PENDAHULUAN}

Pendidikan merupakan salah satu bidang yang sangat penting dan berpengaruh dalam mencetak sumber daya manusia yang berkualitas. Oleh karena itu, pemerintah, sekolah dan masyarakat mempunyai peranan penting dalam memajukan pendidikan.Salah satu upaya yang telah dilakukan pemerintah untuk meningkatkan kualitas pendidikan adalah dengan melakukan perbaikan kurikulum.

Kurikulum yang diterapkan saat ini adalah kurikulum 2013, meskipun sebelumnya belum berlaku untuk semua sekolah SMA/K di Kabupaten Bangli, namun pada tahun pelajaran 2018/2019 semua sekoah SMA/K dari 19 sekloah serentak memberlakukan Kurikulum 2013. Dalam kurikulum 2013, kompetensi lulusan program pendidikan harus mencakup tiga kompetensi, yaitu sikap, pengetahuan, dan keterampilan, sehingga yang dihasilkan adalah manusia Indonesia seutuhnya. Dengan demikian, tujuan pendidikan nasional perlu dijabarkan menjadi himpunan kompetensi dalam tiga ranah kompetensi tersebut.Di dalam 
kurikulum 2013 memandang bahwa setiap peserta didik berada pada posisi sentral dan aktif dalam belajar sehingga guru hanya sebagai fasilitator saja. Penilaian pencapaian kompetensi oleh pendidik dilakukan untuk memantau proses, kemajuan, perkembangan pencapaian kompetensi peserta didik yang diharapkan dapat memberikan umpan balik kepada pendidik agar dapat menyempurnakan perencanaan, pelaksanaan proses pembelajaran dan penilaian hasil belajar.

Berdasarkan hasil supervise Pengawas tingkat Menengah maka kami menemukan beberapa kendala bagi guru dalam menerapkan Kurikulum 2013. Kebanyakan guru belum mendapat pelatihan, pembimbingan dan pendampingan dalam menerapkan Kurikulum 2013 terutama dalam pembuatan Indikator Pencapaian Kompetensi.Kebanyakan guru mengatakan sulit untuk menentukan pemilihan Kata Kerja Oprasional Sikap, Pengetahuan dan Ketrampilan pada perubahan Kurikulum dari KTSP 2006 ke Kurikulum 2013. Dari jumlah sekolah binaan SMA/K sebanyak 19 sekolah yang menerapkan Kurikulum 2013 sebanyak 2 sekolah sejak tahun 2014. Kemudian pada tahun ajaran 2015/2016 semua sekolah secara serentak menerapkan Kurikulum 2013 hanya 1 semester.Berikutnya 2 sekolah yang semula sebagai pilot project tetap menerapkan Kurikulum 2013, yang lain sebanyak 17 sekolah kembali ke Kurikulum 2006/KTSP. Pada tahun ajaran 2017/2018 bertambah lagi 10 sekolah yang menerapkan Kurikulum 2013 dan lagi 7 sekolah yang akan menerapkan Kurikulum 2013 pada tahun ajaran 2018/2019. Sehingga seluruh Sekolah Menengah Atas dan Kejuruan sebanyak 19 sekolah pada tahun Pelajaran 2018/2019 serentak menerapkan Kurikulum 2013. Dari 43 guru binaan hanya 4 orang yang sudah sering dilatih Kurikulum 2013 dan 1 orang yang menjadi tem perumus soal USBN Pendidikan Agama Hindu tahun ajaran 2017/2018.

Berdasarkan data tersebut pengawas melakukan pemantauan kepada seluruh guru binaan pada saat pendampingan penerapan
Kurikulum 2013 ternyata yang menjadi kesulitan bagi guru lebih dominan pada penentuan Indikator Pencapaian Kompetensi sebagai sentral materi pelajaran berdasarkan KI-KD dan Kata Kerja Oprasional Sikap dari A1 sampai A5, Pengetahuan dari C1 sampai C6 dan Ketrampilan dari P1 sampai P4. Seorang guru dalam menuntun siswa dari berpikir tingkat sederhana ke proses berpikir tingkat tinggi, tentunya menyesuaikan dengan karakteristik sekolah, karakteristik siswa dan karakteristik materi ajar.

Belum semua guru memahami standar Permendikbud No 20 tahun 2016 tentang Standar Kompetensi Lulusan, Permendikbud No. 21 tahun 2016 tentang Standar Isi, Permendikbud No. 22 tahun 2016 tentang Standar Proses, Permendikbud No. 23 Tahun 2016 tentang Standar Penilaian dan Permendikbud No 24 tahun 2016 tentang Standar KI-KD mata pelajaran. Itulah sebabnya guru Agama Hindu tingkat SMA/K di Kabupaten Bangli mengahadapi permasahan tentang kualitas kemampuan profesionalisme guru dalam menentukan Indikator Pencapaian Kompetensi sebagai pedoman pembuatan perencanaan Standar Pembelajaran untuk diimplementasikan dalam Proses Belajar Mengajar. Apalagi dalam penilaian ada istilah baru yakni soal Lots, Mots dan Hots sangat sulit untuk di jabarkan dalam bentuk soal-soal sebagai satndar penialain. Semua jenis soal yang akan diinginkan oleh guru dalam penilaian tergantung dari penentuan Indikator Pencapaian Kompetensi penggunaan KKO tingkat berpikir rendah sedang dan tinggi. Beberapa identifikasi permasalahan yang dihadapi guru antara lain:

1. Rendahnya pemahaman guru tentang perubahan kurikulum 2013.

2. Rendahnya kemampuan guru memahami KI-KD dan Indikator Pencapaian Kompetensi sebagai kunci dalam perencanaan, pelaksanaan dan penilaian hasil belajar.

3. Rendahnya kemampuan guru dalam mengimplementasikan RPP sesuai standar Proses. 


\section{RPP yang dipahami sebelumnya belum menunjukan Indikator Pencapaian Kompetensi sebagai pusat perencanaan pembelajaran sesuai harapan Kurikulum yang diimplementasikan dalam PBM.}

5. Rendahnya Kompetensi guru dalam membuat soal yang berstandar dengan indentitas soal lots, mots dan hots, karena belum memahami kata Kerja Oprasional Taksonomi Bloom yang diperbaharui oleh Anderson dalam ranah pengetahuan. Belum memahami Kata kerja Oprasional taksonomi Dyers dalam ranah Ketrampilan. Begitu juga belum memahami Kata Kerja Oprasional taksonomiKrathwohl dalam ranah Sikap, serta belum mampu untuk merangkai KKO dari proses berpikir tingkat sederhana ke proses berpikir tingkat tinggi dan literan.

Begitu banyaknya permasalahan yang dihadapi guru namun yang paling mendasar menjadi pokok permasalahan untuk diteliti adalah rendahnya kemampuan guru dalam membuat Indikator Pencapaian Kompetensi. Hasil pembelajaran akan mencapai tujuan jika perencanaan dari persiapan mengajar memenuhi standar proses, standar pelaksanaan dan standar penilaian. Terutama mampu mengimlementasikan Kata Kerja Oprasional yang tepat pada Indikator Pencapaian Kompetensi ranah Sikap, Pengetahuan, dan Ketrampilan sebagai kunci dalam Pembelajaran.

Tujuan kegiatan ini : (a). untuk meningkatkan prfoesionalisme Guru Agama Hindu tingkat SMA/K diKabupaten Bangli dalam menentukan Indikator Pencapaian Kompetensi Kurikulum 2013. (b). Untuk mengaktifkan MGMP Guru Mata Pelajaran Pendidikan Agama Hindu diKabupaten Bangli melalui workshop pembuatan perangkat Pembelajaran dalam penentuan Indikator Pencapaian Kompetensi.

Menurut Gumelar dan Dahyat (2002:127) merujuk pada pendapat Asian Institut for Teacher Educastion mengemukakan kompetensi Profesional guru pada landasan filosofis, psikologis, dan paedagogik dalam penguasaan perumusan perangkat pembelajaran. Berkaitan dengan kompetensi professi guru, menurut Sagala ( 2006:210).mengemukan sepuluh kompetensi dasar yang harus dimiliki oleh guru yaitu :

1. Menguasai landasan kependidikan

2. Menguasai bahan pelajaran

3. Kemampuan mengelola program belajar mengajar

4. Kemampuan mengelola kelas

5. Kemamapuan mengelola interaksi belajar mengajar

6. Kemampuan Menilai hasil belajar siswa

7. Kemampuan mengenal dan menterjemahkan kurikulum

8. Mengenal pungsi dan program bimbingan danpenyuluhan

9. Memahami prinsip-prinsip dan hasil pengajaran

10. Mengenal dan menyelenggarakan administrasi pendidikan

Menurut Undang-Undang nomor 14

tahun 2005 tentang Guru dan Dosen. Kompetensi professional adalah" kemampuan pengusaan materi pelajaran secara luas dan mendalam".Surya

mengemukakan kompetensi professional adalah berbagai kemampuan yang diperlukan agar dapat mewujudkan dirinya sebagai guru professional. Kompetensi professional meliputi kepakaran atau keahlian dalam bidangnya yaitu penguasaan bahan yang harus diajarkanya beserta metodenya, rasa tanggung jawab akan tugasnya dan rasa kebersamaan dengan sejawat guru lainya.

Berdasarkan beberapa pendapat dari hasil Penelitian Tindakan Sekolah dan Undang-Undang No 14 tahun 2005 tentang Guru dan Dosen bahwa profesionalisme guru merupakan hal mutlak harus dimiliki untuk dapat mengembangkan dan menumbuh kembangkan peserta didik agar berkualitas dalam sikap pengetahuan dan ketrampilanya. Kemampuan mengenal dan menterjemahkan kurikulum sebagai acuan dalam melaksanakan proses pembelajaran sangat perlu untuk dikuasai guru. Inti utama dari isi kurikulum adalah penguasaan KI-KD dan 
Indikator Pencapaian Kompetensi dari masing-masing sikap Spiritual (KI-1 dan KD1), sikap social (KI-2 dan KD-2), Pengetahuan (KI-3 dan KD-3), dan Ketrampilan (KI-4 dan KD-4). Penguasaan Indikator Pencapaian Kompetensi tersebut akan dapat mencerminkan Silabus dan RPP yang mencakup Pendekatan, Metode, Teknik/Strategi Pembelajaran, alat/sumber belajar, media pembelajaran serta penialaian pembelajaran.

Berdasarkan kenyataan tersebut peneliti berinisiatif untuk melakukan penelitianyang dituangkan ke dalam judul penelitian"Peningkatan Profesionalisme Guru dalam Pembuatan Indikator Pencapaian Kompetensi Kurikulum 2013 melalui Work Shop bagi Guru Pendidikan Agama Hindu tingkat SMA/K di Kabupaten Bangli Tahun Pelajaran 2018/2019”.

\section{Metodologi Penelitian}

Metode yang dipakai untuk mengumpulkan data penelitian ini adalah wawancara dan observasi. Wawancara adalah untuk memperoleh informasi yang diperlukan untuk melengkapi data dalam penelitian, maka wawancara sangat penting diperlukan untuk kelancaran proses penelitian (Singarimbun, 1995:175). Teknik wawancara/Interview adalah pecakapan langsung antara pewawancara dengan yang diwawamcarai.

Daftar wawancara dibuat berupa pertanyaan-pertanyaan dipegang oleh peneliti dalam bentuk wawancara antara peneliti dengan subjek yang diteliti dan mengisi daftar wawancara pihak peneliti (Sigit, 2001:100). Pedoman wawancara berguna untuk menghindari kehabisan bahan pertayaan. Wawancara akan lancar jika dapat dirumuskan pertanyaan-pertanyaan dengan sempurna, dan hal itu mata tergantung pada sisi pertanyaan. Isi pertanyaan sebagai pedoman wawancara erat hubunganya dengan pengetahuan peneliti tentang isi pokok permasalahan pada pedoman wawancara yang dipergunakan.
Observasi merupakan teknik penilaian yang dilakukan secara berkesinambungan dengan menggunakan indera, baik secara langsung maupun tidak langsung dengan menggunakan instrumen yang berisi sejumlah indikator perilaku yang diamati. Observasi langsung dilaksanakan oleh pengawas secara langsung tanpa perantara orang lain. Bentuk instrumen yang digunakan untuk observasi adalah pedoman observasi yang berupa daftar cek atau skala penilaian (rating scale) yang disertai rubrik. Daftar cek digunakan untuk mengamati ada tidaknya suatu sikap atau perilaku. Sedangkan skala penilaian menentukan posisi sikap atau perilaku guru dalam suatu rentangan sikap dan ketrampilan mengerjakan materi IPK saat workshop. Pedoman observasi secara umum memuat pernyataan sikap atau perilaku yang diamati dan hasil pengamatan sikap atau perilaku sesuai kenyataan. Pernyataan memuat sikap atau perilaku yang positif atau negatif sesuai indikator penjabaran sikap dalam kompetensi inti dan kompetensi dasar.

Pedoman observasi dilengkapi juga dengan rubrik dan petunjuk penskoran. Rubrik memuat petunjuk/uraian dalam penilaian skala atau daftar cek. Sedangkan petunjuk penskoran memuat cara memberikan skor dan mengolah skor menjadi nilai akhir. Agar observasi lebih efektif dan terarah hendaknya :

1. Dilakukan dengan tujuan jelas dan direncanakan sebelumnya. Perencanaan mencakup indikator atau aspek yang akan diamati dari suatu proses.

2. Menggunakan pedoman observasi berupa daftar cek atau skala penilaian.

3. Pencatatan dilakukan selekas mungkin.

4. Kesimpulan dibuat setelah program observasi selesai dilaksanakan.

Metode yang digunakan dalam penelitian ini adalah deskriptif kualitatif, yaitu data yang diperoleh dihimpun dan dianalisa sesuai keadaan dan situasi yang sebenarnya dengan tolak ukur ketentuandan undangundang yang berlaku, yaitu dengan cara menghimpun informasi secara mendalam mengenai keadaan dan kondisi sebenarnya 
dalam pemberian tindakan pada kegiatan MGMP .

Indikator keberhasilan penelitian ini adalah pada siklus I guru-guru dianggap berhasil apabila mencapai peningkatan kemampuan membuat IPK sesuai instrument yang dipakai mengukur keberhasilan dari sebelumnya. Pada siklus II diharapkan kemampuan guru meningkat pemahamnya terhadap kekurangan yang dialami guru saat workshop IPK seperti kurang mengoptimalkan penggunaan Laptop, kurang kreativitas dalam mencari sumber peraturan yang berlaku, berinisiatif, kurang tanggap dan kurang mampu mempresentasikan hasil kinerjanya untuk meningkatkan nilai. Pada siklus III para guru diharapkan sudah mampu tampil menyajikan IPK sesuai Kurikulum 2013 untuk diterapkan dalam pembuatan Silabus, dan RPP dan nilainya mengalami peningkatan. Pemahaman konsep pembelajaran yang efektif, kreatif, inovatif, dan kolaboratif, membuat dan mengisi format serta menguasai langkah-langkah pembelajaran pelaksanaan workshop Indikator Pencapan Kompetensi pada Kurikulum 2013. Pemberian tindakan achievement motivation training dan peer teaching ini efektif jika para guru mampu meningkatkan motivasi belajar peserta workshop aktif, kreatif, dan guru berperan sebagai narasumber, motivator, fasilitator serta mediator dalam Proses Belajar Mengajar berpedoman pada IPK. Penayajian materi ajar yang sesuai dengan tujuan pembelajaran menyajikan pembelajaran dengan menyenangkan dapat mencapai poin baik. Berdasarkan peraturan dari Direktur Jendral Pendidikan Tinggi Depdiknas, 2007, poin penilaian untuk kemampuan pengelolaan peragkat pembelajaran bagi guru adalah:

Skor $1=$ Tidak Baik nilai 49 ke bawah $=$ E

Skor $2=$ Kurang Baik nilai $50-60=\mathrm{D}$

Skor $3=$ Cukup 61-75 = C

Skor $4=$ Baik 76-85 = B

Skor $5=$ Sangat baik 86-100=A

Peserta workshop dinyatakan berhasil jika mengalami peningkatan profesional minimal mendapat predikat cukup atau nilai minimal 75 pada penilaian kinerja, dari ketiga siklus yang dilaksanakan.

\section{HASIL DAN PEMBAHASAN}

Berdasarkan data hasil refleksi awal setelah dilaksanakan wawancara tentang standar isi dan muatan kurikulum serta proses pembelajaran, guru masih awam tentang Permendikbud nomor 20 tahun 2016 tentang Standar Kompetensi Lulusan, Permendkbud 21 tahun 2016 tentang standar isi, Permendikbud nomor 24 tahun 2016 tentang Kompetensi Inti-Kompetensi Dasar Pelajaran pada Kurikulum 2013 serta Permendikbud nomor 22 tahun 2016 tentang Standar Proses yang menjadi pedoman menyiapkan rencana pelaksanaan pembelajaran diawali dengan membuat Indikator Pencapaian Kompetensi. Pada siklus I diawali dengan uji kompetensi berupa pedomana wawancara yang mesti dijawab semua guru agama Hindu tingkat SMA/K di Kabupaten Bangli. Standarisasi yang ditetapkan pada guru agama sebagai pemenuhan indikator kinerja minimal Guru agama Hindu dalam pemahaman KI-KD, taksonomi yang dituangkan ke dalam format pembuatan Indkator Pencapaian Kompetensi. Berdasarkan pemahaman standar isi dan standar Kompetensi Inti-Kompetensi Dasar Pelajaran Pendidikan Agama Hindu tingkat Menengah di SMA/K pada Kurikulum 2013 bagi guru jika mencapai nilai baik atau skor 4 . Ternyata hasil tes menunjukan pencapaian nilai tertinggi guru agama Hindu tingkat SMA/K Kabupaten Bangli hanya 6 orang mencapai predikat baik atau skor 4. Sedangkan 9 orang mencapai niali cukup dengan angka tertinggi 70 predikat cukup, sedangkan 20 orang memperoleh nilai terendah skor 2 dengan angka 50 predikat kurang baik. Hal ini sangat diperlukan adanya upaya peningkatan sehingga guru mampu mencapai standar idial atau standar ketuntasan minimum. Nilai hasil uji kompetensi paedagogik terkait pembuatan Indikator Pencapaian Kompetensi guru agama Hindu tingkat SMA/K Kabupaten Bangli masih rendah. Sebagian besar masih di bawah 
standar kompetensi yang ditetapkan yakni nilai 76. Diharapkan dengan pelaksanaan pembinaan dan workshop/pelatihan pembuatan Indikator Pencapaian Kompetensi kemampuannya meningkat dalam penguasaan KI-KD, taksonomi kata kerja oprasional yang dituangkan dalam Silabus dan RPP mencapai ketuntasan minimum predikat baik atau ada peningkatan kemampuan bahkan agar mencapai predikat sangat baik. Untuk itu peneliti berupaya merubah strategi workshop/pelatihan dan pembinaan peningkatan kemampuan membuat Indikator Pencapaian Kompetensi dengan metode unjuk kerja imbas teman sejawat. Tujuanya adalah untuk lebih mengefektifkan waktu, pembina lebih mudah mengontrol kekurangan masing-masing guru karena jumlahnya sedikit. Perhatian guru yang dibina tidak bias serta sedikit kemungkinan guru dapat ngobrol ketika sedang serius ddilatih/ibina. Harapanya bahwa lebih cepat dapat diperbaiki dan dilatih dengan metode unjuk kerja agar mampu mengajawantahkan KI-KD dan taksonomi KKO ke dalam Indikator Pencapaian Kompetensi sebagai sentral perangkat pembelajaran yang standar sesuai pedoman dan petunjuk teknis implementasi Kurikulum 2013.

Hasil Penilaian Masing-Masing Siklus

a. Hasil Siklus I

Pada siklus I dari 35 guru agama Hindu yang dilatih dan dilakukan penilaian ternyata yang mendapat predikat kurang baik sebanyak 17 orang, predikat cukup 12 orang dan predikat baik 6 orang.

b. Hasil Sklus II

Peningkatan perubahan pemahaman terhadap pembuatan Indikator Pencapaian Kompetensi yang dialami oleh guru agama Hindu tingkat SMA/K Kabupaten Bangli pada siklus I dapat dilihat perubahanya. Setelah diberikan pemahaman praktek pembuatan Indikator Pencapaian Kompetensi terjadi peningkatan yang signifikan. Dari awalnya di siklus I ada mendapat predikat kurang baik di siklus II menjadi tidak ada yang kurang baik. Hasil penilaian dari 35 orang guru yang dilatih 20 orang mendapat nilai cukup, 11 orang mendapat predikat baik dan 4 orang mendapat predikat sangat baik.

c. Hasil Siklus III

Pada siklus ketiga juga mengalami penigkatan yang sangat signifikan walaupun belum semuanya memmenuhi ketentuan persyaratan minimal dengan predikat baik. Perkembangan kemampuan guru meningkat tajam, dari 35 guru yang dilatih dan dinilai hasilnya sebagai berikut : 12 orang mendapat predikat cukup, 16 orang mendapat predikat baik dan 7 orang mendapat predikat sangat baik.

Hasil setiap siklus dalam penelitian ini senantiasa mengalami peningkatan walaupun belum semuanya memenuhi kreteria ketuntasan minimal dengan predikat baik. Baru satu tahapan dilaksanakan pelatihan Proses pelatihan membuat Indikator Pencapaian Kompetensi sudah mengalami peningkatan profesionalisme guru yang sangat menggembirakan. Semua peserta pelatihan meminta pembinaan dan pelatihan dilanjutkan walaupun secara swakarsa dan mandiri dalam wadah MGMP. Bahkan tindaklanjut dari pengawas agar senantiasa dilakukan observasi kelas dan refleksi saat guru mengajar di kelas. Hal tersebut dilakukan untuk dapat mengukur ketepatan penggunaan KKO masing-masing ranah berdasarkan kata kunci pada KD. Harapanya agar semua proses dapat dipantau secara nyata tanpa dibuat-buat dan guru lain/teman sejawat dapat menambah wawasan dengan mendapat imbas pengalaman sekolah lain.

\section{KESIMPULAN}

Berdasarkan hasil analisis data dapat disimpulkan bahwa kegiatan workshop MGMP dapat meningkatkan kemampuan Guru Agama Hindu tingkat SMA/K di Kabupaten Bangli dalam membuat Indikator Pencapaian Kompetensi Kurikulum 2013. Hasil masing-masing siklus dapat meningkatan profesionalisme guru yakni Pada siklus I dari Pada siklus I dari 35 guru 
agama Hindu yang dilatih dan dilakukan penilaian ternyata yang mendapat predikat kurang baik sebanyak 17 orang, predikat cukup 12 orang dan predikat baik 6 orang.

Dari awalnya di siklus I ada mendapat predikat kurang baik di siklus II menjadi tidak ada yang kurang baik. Hasil penilaian dari 35 orang guru yang dilatih 20 orang mendapat nilai cukup, 11 orang mendapat predikat baik dan 4 orang mendapat predikat sangat baik.

Pada siklus ketiga juga mengalami penigkatan yang sangat signifikan walaupun belum semuanya memmenuhi ketentuan persyaratan minimal dengan predikat baik namun indikator pencapaian keberhasilan telah tercapai peserta workshop minimal mendapat nilai cukup. Perkembangan kemampuan guru meningkat tajam, dari 35 guru yang dilatih dan dinilai hasilnya sebagai berikut : 12 orang mendapat predikat cukup, 16 orang mendapat predikat baik dan 7 orang mendapat predikat sangat baik.

\section{SARAN}

Berdasarkan simpulan hasil penelitian dan pembahasan, maka kami sampaikan saran sebagai berikut:

1. Kepada guru Pendidikan Agama Hindu agar senantiasa mengikuti KKG/MGMP serta pembinaan dan Pelatihan baik di Gugus di Kecamatan maupun di Kabupaten untuk memperluas dan memperdalam pengetahuan dibidang pendidikan untuk senjata mengajar agar guru selalu merasa percaya diri tampil di depan kelas.

2. Kepada para pengawas untuk senantiasa melakukan Inovasi pembelajaran, khususnya yang berhubungan dengan metode peningkatan kualitas guru melakukan pelatihan peningkatan kulaitas dan profesionalisme guru melalui KKG/MGMP.

3. Kepada lembaga Pendidikan, khususnya lembaga pendidikan formal agar mendorong dan momotivasi Pengawas dan Guru untuk senantiasa meningkatkan kemampuannya, sehingga kualitas proses pembelajaran dapat ditingkatkan untuk meningkatkan hasil belajar.

\section{DAFTAR PUSTAKA}

Dahar, Ratna Wilis. 1989. Teori-Teori Belajar. Jakarta: Penerbit Erlangga.

Depdikbud. 1994. Petunjuk Pelaksanaan Proses Belajar-Mengajar. Jakarta: Direktorat Pendidikan Menengah Umum.

Depdiknas. 1999. Pengelolaan Pengujian Bagi Guru Mata Pelajaran. Jakarta: Direktorat Pendidikan Menengah Umum, Direktorat Jenderal Pendidikan Dasar dan Menengah

Depdiknas. 2002. Contextual Teaching And Learning. Jakarta: Dirjen Pendidikan Dasar dan Menengah.

Degeng I Nyoman S, 2006. Teori dan Konsep Belajar, Surabaya: Program Pascasarjana Universitas PGRI Adibuana.

Depdiknas, 2003. Undang-Undang Republik Indonesia Nomor 20 Tahun 2003 tentang Sistim Pendidikan Nasional, Jakarta: Depdiknas.

Depdiknas, 2005. Undang-Undang Nomor 14 tentang Guru dan Dosen.

Depdiknas, 2005. Peraturan Pemerintah Republik Indonesia Nomor 19 Tahun 2005 tentang Standar Nasional Pendidikan, Jakarta: Mendiknas.

Depdiknas, 2006. Pedoman Pelaksanaan Penelitian Tindakan Kelas, Jakarta: Dit Prodik Dirjen PMPTK.

Depdiknas, 2008. Peraturan Pemerintah nomor 74 tentang Guru, Jakarta.

Departemen Agama RI, 2009. Peraturan Menteri Agama No 16 Tahun 2009 tentang Penyelenggaraan Pendidikan Agama di Sekolah, Jakarta.

Dwi Agus Sudjimat, 2004. Metodelogi Penelitian, Surabaya: Program Pascasarjana Universitas PGRI Adibuana.

Indrawati dan Maman Wijaya, 2001. Penelitian Tindakan Kelas, Bandung: PPPG IPA Depdiknas. 
Kemendikbud, 2016 Permendikbud No 20 tentang Standar Kompetensi Lulusan.

Kemendikbud, 2016 Permendikbud No 21 tentang Standar Isi.

Kemendikbud, 2016 Permendikbud No 22 tentang Standar Proses Pemebelajaran

Kemendikbud,2016 Permendikbud No 24 tentang Kompetensi Inti dan Kompetensi Dasar 